\title{
Up-regulation of oxytocin receptors in non-pregnant rat myometrium by isoproterenol: effects of steroids
}

\author{
T Engstrøm ${ }^{1,2}$, P Bratholm ${ }^{1}$, N J Christensen ${ }^{1}$ and $\mathbf{H}$ Vilhardt $^{2}$ \\ ${ }^{1}$ Department of Internal Medicine and Endocrinology, Herlev Hospital, University of Copenhagen, 2730 Herlev, Denmark \\ ${ }^{2}$ Department of Medical Physiology, The Panum Institute, University of Copenhagen, 2200 Copenhagen N Herlev, Denmark \\ (Requests for offprints should be addressed to T Engstrøm, Department of Endocrinology, Herlev Hospital, University of Copenhagen, 2730 Herlev, Denmark)
}

\begin{abstract}
The objective of the present study was to further elucidate our previous observation that $\beta_{2}$-adrenoceptor activation induces oxytocin receptor (OTR) expression in rat myometrium. We wanted to investigate whether the mechanism behind this effect was under the influence of gonadal steroids. Ovariectomized non-pregnant rats were treated with estrogen, progesterone or a combination of both for 3 days. Some rats were concomitantly treated with isoproterenol.

Estrogen treatment increased both OTR mRNA production and maximal binding of $\left[{ }^{3} \mathrm{H}\right]$-oxytocin to isolated myometrial plasma membranes, but it did not affect contractility of isolated uterine strips challenged with oxytocin. When the estrogen regimen was combined with isoproterenol treatment, an augmented maximal contractile response $\left(\mathrm{E}_{\max }\right)$ to oxytocin was observed although no
\end{abstract}

further increase in OTR mRNA and binding was seen. Progesterone treatment did not in itself alter OTR mRNA, OTR binding or $\mathrm{E}_{\max }$. However, OTRs were induced at the level of gene expression when progesterone was supplemented with isoproterenol infusion. Finally, progesterone suppressed the effect of estrogen on OTR mRNA production and binding when the two compounds were administered together. However, when isoproterenol treatment was added this effect was abolished and $\mathrm{E}_{\max }$ was enhanced more than that seen following treatment with estrogen alone.

These data suggest that $\beta_{2}$-adrenoceptor activation represents an important regulator of OTR expression/ function in estrogen- and progesterone-dominated rat myometrium.

Journal of Endocrinology (1999) 161, 403-411

\section{Introduction}

Oxytocin receptors (OTRs) increase in the endometrium (Sheldrick \& Flint 1985) during luteolysis and in myometrial tissue at term (Fuchs et al. 1992). Since steroid hormones, in particular progesterone and estrogens, are thought to play pivotal roles in the process of luteolysis and in the initiation, maintenance and termination of pregnancy, it is not surprising that these substances should participate in the regulation of OTR concentrations. The precise mechanisms by which these gonadal steroids influence OTR formation and function are, however, not fully elucidated. The OTR gene comprises an estrogen response element, which imparts estrogen inducibility of OTR gene transcription (Bale \& Dorsa 1997). In spite hereof, the results concerning the effects of estrogens on OTR have not been unequivocal. Thus, in some studies estrogens have been shown to increase the amount of uterine OTR mRNA (Quinones Jenab et al. 1997) and the number of OTR binding sites (Hixon \& Flint 1987), while in others, estradiol has been reported to decrease uterine OTR concentrations (Silvia et al. 1991, Sheldrick
\& Flick Smith 1993). On the other hand, the effects of progesterone on uterine OTR are, in general, agreed to be suppressive (Vallet et al. 1990, Lau et al. 1992). This effect may primarily be of a non-genomic character, due to the lack of a progesterone response element in the OTR gene. Thus, Grazzini et al. (1998) found progesterone to inhibit OTR function by direct binding to the OTR. In bovine endometrium a 200 -fold rise in OTR was proceeded by a decline in plasma progesterone (Fuchs et al. 1992). Indeed, the decline in plasma progesterone observed in some species at term has been suggested to be the stimulus that triggers the up-regulation of myometrial OTR and thereby initiates delivery (Hilliard et al. 1968).

Several observations indicate that hormones other than steroids also regulate OTR. These include oxytocin itself (Engstrøm et al. 1988a) and substances capable of stimulating cAMP production (Jeng et al. 1995). We recently showed that $\beta_{2}$-adrenoceptor stimulation by isoproterenol increased rat myometrial OTR gene expression (Engstrøm et al. 1998). In accordance, Bale \& Dorsa (1998) recently identified a novel region of the rat OTR promoter containing elements, which impart cAMP inducibility of 
OTR gene transcription. In this context however, it is intriguing that some studies have shown that the cAMP analogue CPTcAMP inhibits the function of OTR (Anwer et al. 1989,1990) and we speculate whether our previous observed effect of isoproterenol infusion on OTR dynamics is dependent also on gonadal steroids in the myometrial compartment. Thus, Jeng et al. (1995) have previously described a synergistic effect of cortisol and the cAMP elevating agent forskolin in elevating OTR concentrations in rabbit amnion cells.

The objective of the present study was to investigate the effect of isoproterenol infusion in ovariectomized rats on myometrial OTR binding, oxytocin induced uterine contractility and myometrial OTR gene expression, after pre-treatment with estrogen and progesterone alone or in combination.

\section{Materials and Methods}

\section{Animals}

Female Wistar rats $(250-350 \mathrm{~g})$ were maintained under controlled conditions in the Panum Institute Animal House. Food and water were freely available. All experiments conformed to the Guidelines on the Handling and Training of Laboratory Animals by Universities Federation for Animal Welfare.

Rats were anesthetized with a mixture of Dormicum $(1.25 \mathrm{mg}$, Roche, Basel, Switzerland) and Hypnorm $(0.4 \mathrm{ml}$, Janssen, Geel, Belgium). Through an incision in the lateral abdominal wall the rats were bilaterally ovariectomized. Thereafter, the incisions were sutured. Eight treatment groups were formed 7 days later. The groups received either no steroid injection (groups 1-2), a daily i.m. injection of $50 \mu \mathrm{g}$ estradiol-benzoate (LEO, Copenhagen, Denmark, groups 3-4) (Stürmer 1968), a daily i.m. injection of $100 \mu \mathrm{g}$ progesterone (Sigma Chemical Company, St Louis, MO, USA, groups 5-6) or both steroids (groups 7-8) for 3 consecutive days. The higher dosage of progesterone compared with estradiol-benzoate was chosen due to the high metabolic degradation rate of progesterone (Ganjam et al. 1975). During the steroid treatment period the rats were additionally given continuous infusions of isoproterenol $(10 \mu \mathrm{g} / \mathrm{h}$, Sigma Chemical Company, groups $1,3,5,7)$ or saline (groups 2, 4, 6, 8) by means of osmotic mini-pumps (Engstrøm et al. 1998). The dosage regime of isoproterenol was selected from preliminary experiments in which $10 \mu \mathrm{g} / \mathrm{h}$ was found to be the minimal effective dose on OTR transcription. Following the treatment period the rats were anesthetized with $\mathrm{CO}_{2}$ and decapitated. The abdomen was opened longitudinally and the uterine horns were removed. Some uterine horns were used for measurements of in vitro contractility. Others were freed from endometrium and parametrium and were subsequently used for isolation of mRNA or plasma membranes.
Primers and construction of internal $m R N A$ standard

The oligonucleotide primers (DNA Technology, Aarhus, Denmark) used for detection of OTR mRNA were selected from a sequence published by Rozen et al. (1995) using a computer program (Oligo Primer Analysis, National Biosciences, Plymouth, MN, USA):

Sense primer: 5' GGG ACG TCA ATG CGC CCA AGG AA 3' (nucleotides 2816-2838)

Antisense primer: $5^{\prime}$ ACC AAT AGA CAC CTA ATG CA 3' (nucleotides 3921-3940)

Basic local alignment search tool (Blast) (Altschul et al. 1990) was used to search all non-redundant databases $($ GenBank+EMBL+DDBJ+PDB) for sequence homology. No homology with any known products other than the rat OTR was found. The amplified OTR DNA fragments consisted of $375 \mathrm{bp}$. The exact identity of the PCR product was confirmed by sequencing (Engstrøm et al. 1998). Using a PCR-MIMIC construction kit (Clontech, Palo Alto, CA, USA) an internal 240 bp DNA standard was constructed (Engstrøm et al. 1997). The internal standard RNA was constructed mainly as described by Faure et al. (1995). A composite primer, comprising 37 nucleotides of bacteriophage T7 RNApolymerase promoter followed by the sequences of our usual sense primers, was used for amplification of the 240 bp DNA sequence by PCR. The resulting $277 \mathrm{bp}$ product was re-amplified using our antisense primers and a primer consisting of the initial 23 nucleotides of the T7 RNA-polymerase promoter region. Following HPLC purification the re-amplified products were used for production of RNA by in vitro transcription (Riboprobe, Promega, Madison, WI, USA). The resulting RNA standards were quantitated by UV detection at $260 \mathrm{~nm}$ (Gene-quant, Pharmacia, Stockholm, Sweden). Subsequently the RNA standards underwent reverse transcription ( $\mathrm{RT}$ ) in order to verify that the resulting products were indistinguishable from the internal DNA standard.

\section{Isolation of myometrial $m R N A$}

The isolation of poly $(\mathrm{A}+)$ mRNA was performed using a MicroPoly(A)Pure kit (Ambion Inc., Austin, TX, USA). Approximately $30-300 \mathrm{mg}$ myometrium free from paraand endometrium were homogenized in $800 \mu \mathrm{l}$ lysis solution. An aliquot was mixed with two volumes dilution buffer. Tissue debris was removed by centrifugation for $10 \mathrm{~min}$ at $12000 \mathrm{~g}$ and $4{ }^{\circ} \mathrm{C}$. A total of $1 \mathrm{ml}$ supernatant was combined with $20 \mathrm{mg}$ oligo dT resin and agitated for $60 \mathrm{~min}$ at room temperature. The oligo $\mathrm{dT}$ resin was washed thrice with $1 \mathrm{ml}$ binding buffer followed by three washings with $1 \mathrm{ml}$ wash buffer. It was subsequently transferred to a spin column and centrifuged at $5000 \mathrm{~g}$ at room temperature. A total of $500 \mu \mathrm{l}$ wash buffer was added to the column and the oligo dT resin re-centrifuged. To 
ensure complete removal of ribosomal RNA this step was repeated until the absorbance of the flow-through wash at $260 \mathrm{~nm}$ was below $0 \cdot 05$. Poly(A+) mRNA was thereafter eluted with $200 \mu \mathrm{l} 65^{\circ} \mathrm{C}$ elution buffer followed by overnight precipitation in $20 \mu \mathrm{l} 5 \mathrm{M} \mathrm{NH} \mathrm{NH}_{4} \mathrm{OAC}, 1 \mu \mathrm{l}$ glycogen $(5 \mathrm{mg} / \mathrm{ml})$ and $500 \mu \mathrm{l} 96 \%$ ethanol. The solution was centrifuged at $15000 \mathrm{~g}$ for $20 \mathrm{~min}$ at $4{ }^{\circ} \mathrm{C}$, the pellet washed with $70 \%$ ethanol to remove remaining salts and finally the pellet was resuspended in DEPC $-\mathrm{H}_{2} \mathrm{O}$ and stored frozen at $-80{ }^{\circ} \mathrm{C}$.

\section{RT-PCR}

RT was performed in a mixture consisting of $250 \mu \mathrm{M}$ dNTP, $40 \mathrm{U}$ MMLV-RT (Promega), 31.2 U RNAguard, 200 pmol antisense primer and $5 \mu$ internal RNA standard in Promega RT buffer. Incubations were carried out for $60 \mathrm{~min}$ at $37^{\circ} \mathrm{C}$ and the resulting cDNA used immediately or stored at $-80^{\circ} \mathrm{C}$.

PCR was carried out with $5 \mu \mathrm{l}$ cDNA, $37 \cdot 5 \mu \mathrm{M}$ of each dNTP, 1.0 U Taq polymerase (Pharmacia, Stockholm, Sweden), 40 pmol sense primer and antisense primer in PCR buffer (10 mM Tris- $\mathrm{HCl}, 50 \mathrm{mM} \mathrm{KCl}, 1.5 \mathrm{mM}$ $\mathrm{MgCl}_{2}, \mathrm{pH}$ 9.0). Amplification took place in a Perkin Elmer Model 460 thermocycler. Cycling parameters were: $95^{\circ} \mathrm{C}$ for $2 \mathrm{~min}$ followed by 27 cycles consisting of $1.5 \mathrm{~min}$ at $94^{\circ} \mathrm{C}, 56{ }^{\circ} \mathrm{C}$ for $45 \mathrm{~s}$ and $70{ }^{\circ} \mathrm{C}$ for $2 \mathrm{~min}$. After the last cycle the incubations continued for $5 \mathrm{~min}$ at $72{ }^{\circ} \mathrm{C}$ followed by lowering of the temperature to $4{ }^{\circ} \mathrm{C}$. PCR products were used immediately or stored at $-80{ }^{\circ} \mathrm{C}$.

Quantitation of PCR products was carried out by means of HPLC using a TSK DEAE-NPR column (Engstrøm et al. 1997). Following chromatography PCR products were detected by UV at $254 \mathrm{~nm}$ (Fig. 1). The area of the $240 \mathrm{bp}$ PCR products of the internal standard represented 0.050 amol. Hence, the amounts of the $375 \mathrm{bp}$ PCR products could be quantitated relative to this standard and it was finally related to tissue wet weight. The average value of the uterine horns of each animal was calculated to represent the amount of specific mRNA.

\section{Binding of $\left[{ }^{3} \mathrm{H}\right]$-oxytocin to isolated myometrial plasma membranes}

Preparation of rat myometrial plasma membranes was performed by subcellular fractionation (Engstrøm et al. 1988b). Subsequent binding of ${ }^{3} \mathrm{H}$-oxytocin was carried out as previously described (Engstrøm et al. 1988a). Plasma membranes were incubated for $60 \mathrm{~min}$ with concentrations of ${ }^{3} \mathrm{H}$-oxytocin varying from $0 \cdot 42$ to $24 \cdot 20 \mathrm{nM}$ (New England Nuclear, Boston, MA, USA; specific activity $35 \cdot 0 \mathrm{Ci} / \mathrm{mmol}$ ). The assay was performed at room temperature and initiated by the addition of plasma membranes. At the end of the incubation period bound ligand was separated from unbound by filtration. Specific binding of $\left[{ }^{3} \mathrm{H}\right]$-oxytocin was calculated by subtraction of

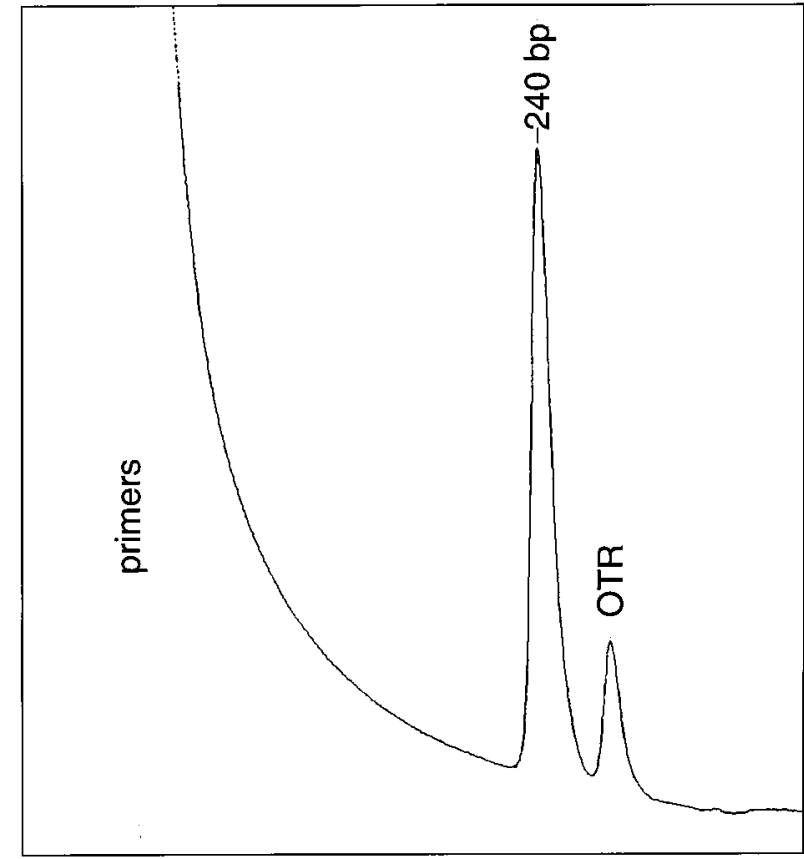

Figure 1 HPLC trace of PCR products. The internal standard RNA is indicated by the $240 \mathrm{bp}$ product and represents $0.050 \mathrm{amol}$. The OTR product is represented as indicated. By comparing the areas under the curves of the two products it is possible to calculate the amount of OTR present in the tissue specimen.

binding in the presence of a 1000-fold excess of unlabeled oxytocin and was finally related to protein content ad modium Lowry et al. (1951). To ensure that the effect of isoproterenol infusion on the subsequent binding of ${ }^{3} \mathrm{H}-$ oxytocin was not caused by residual isoproterenol in the plasma membrane preparation we investigated the ability of isoproterenol to affect ${ }^{3} \mathrm{H}$-oxytocin binding. ${ }^{3} \mathrm{H}-$ oxytocin at concentrations of 6.05 and $12.10 \mathrm{nM}$ was incubated in the presence and absence of $1 \mu \mathrm{M}$ isoproterenol. Binding of the tritiated ligand was unaffected by isoproterenol.

In vitro examination of contractile force of myometrial strips

In vitro contractility was measured as described previously (Engstrøm et al. 1997). One uterine horn was opened longitudinally and a middle segment measuring $5 \mathrm{~mm}$ was mounted in an isometric myograph connected to a Grass force transducer, the resting tension being $1.5 \mathrm{~g}$. The strip was placed in an organ bath containing $8 \mathrm{ml}$ Munsick's buffer, $30^{\circ} \mathrm{C}$, pH $7 \cdot 4$ (Munsick 1960) and allowed to rest for $30 \mathrm{~min}$. Every $10 \mathrm{~min}$ during this period the buffer was refreshed in order to wash out any isoproterenol potentially remaining in the tissue specimen. Before stimulation with oxytocin the specimens were further washed five times. The tissue was thereafter contracted with $50 \mathrm{mM} \mathrm{KCl}$. Contractile responsiveness to oxytocin doses in the range 


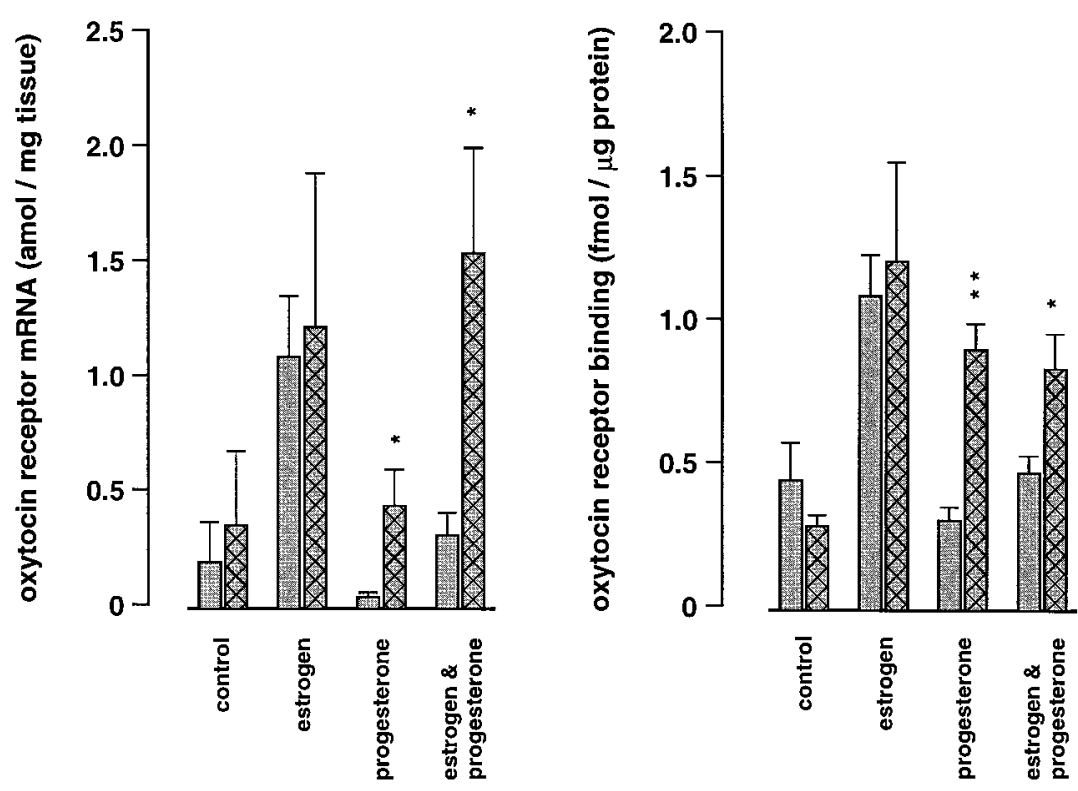

Figure 2 OTR mRNA (left panel) and OTR binding (right panel) following treatment for 3 days with estradiol-benzoate $(50 \mu \mathrm{g} \times 1$, i.m. $)$, progesterone $(100 \mu \mathrm{g} \times 1$, i.m. $)$ or a combination of both (same doses as in individual regimens). Crosshatched bars indicate additional treatment with isoproterenol $(10 \mu \mathrm{g} / \mathrm{h})$ for 3 days whereas grey bars indicate additional treatment with saline $(1 \mu \mathrm{l} / \mathrm{h})$ for 3 days. ${ }^{*} P<0 \cdot 05$ and ${ }^{*} P<0 \cdot 001$ when isoproterenol was substituted with saline. Values are means \pm S.E.M., $n=3-5$.

of $0.63 \times 10^{-10}-0.13 \times 10^{-6} \mathrm{M}$ was measured. Following stimulation with $\mathrm{KCl}$ and following every stimulation with oxytocin the chamber was washed five times with Munsick's buffer. During the experiment the buffer was constantly aerated with $5 \% \mathrm{CO}_{2}$ in $\mathrm{O}_{2}$. Responses following oxytocin stimulation were expressed as a percentage of the potassium induced contraction and were plotted against the logarithm to the agonist concentration.

\section{Data analysis}

A computer program (Fig. P., Biosoft, Cambridge, UK) was used for data analysis. A four-parameter non-linear curve-fitting model was used to evaluate myometrial responsiveness to oxytocin. Maximal contraction $\left(\mathrm{E}_{\max }\right)$ and the agonist concentration giving half this effect (EC50) were obtained from curve-fits of individual dose-response curves using the equation: $\mathrm{E}=\mathrm{E}_{\min }+\left(\mathrm{E}_{\max }-\mathrm{E}_{\min }\right) /(1+$ $\left.\left(([\mathrm{OT}] / \mathrm{EC} 50)^{-\mathrm{P}}\right)\right)$.

Specific binding data from saturation binding experiments were analyzed using the equation: specific binding = $\left[{ }^{3} \mathrm{H}-\mathrm{OT}\right] \times \mathrm{B}_{\max } /\left(\left[{ }^{3} \mathrm{H}-\mathrm{OT}\right]+K_{\mathrm{D}}\right)$. Subsequently maximal specific binding $\left(\mathrm{B}_{\text {max }}\right)$ and dissociation constants $\left(K_{\mathrm{D}}\right)$ were obtained from linear regression of individual double reciprocal plots following the equation: $1 /$ specific binding $=$ $1 / \mathrm{B}_{\max }+K_{\mathrm{D}} / \mathrm{B}_{\max } \times 1 /\left[{ }^{3} \mathrm{H}-\mathrm{OT}\right]$.
One way analysis of variance or Kruskal-Wallis tests were used to compare multiple groups. Significant effects among individual means were subsequently separated using post-hoc tests for multiple comparison (StudentNewman-Keuls or Dunn's method). Student's $t$-test or the Mann-Whitney test were used to determine whether mRNA, receptor binding or in vitro contractility following isoproterenol treatment were statistically different from saline values. $P<0.05$ was considered statistically significant. Results are presented as means \pm s.E.M. unless otherwise stated.

\section{Results}

\section{OTR $m R N A$}

Myometrial OTR mRNA results are shown in Fig. 2. Analysis of variance revealed an overall statistical difference between the steroid treatment groups not receiving isoproterenol $(P=0 \cdot 003)$. Subsequent post-hoc tests showed that estrogen treatment increased OTR mRNA when compared with the vehicle group $(P<0 \cdot 05)$. When estrogen was administered together with progesterone this effect did, however, disappear. Progesterone treatment did not in itself significantly change OTR mRNA when compared with vehicle. 

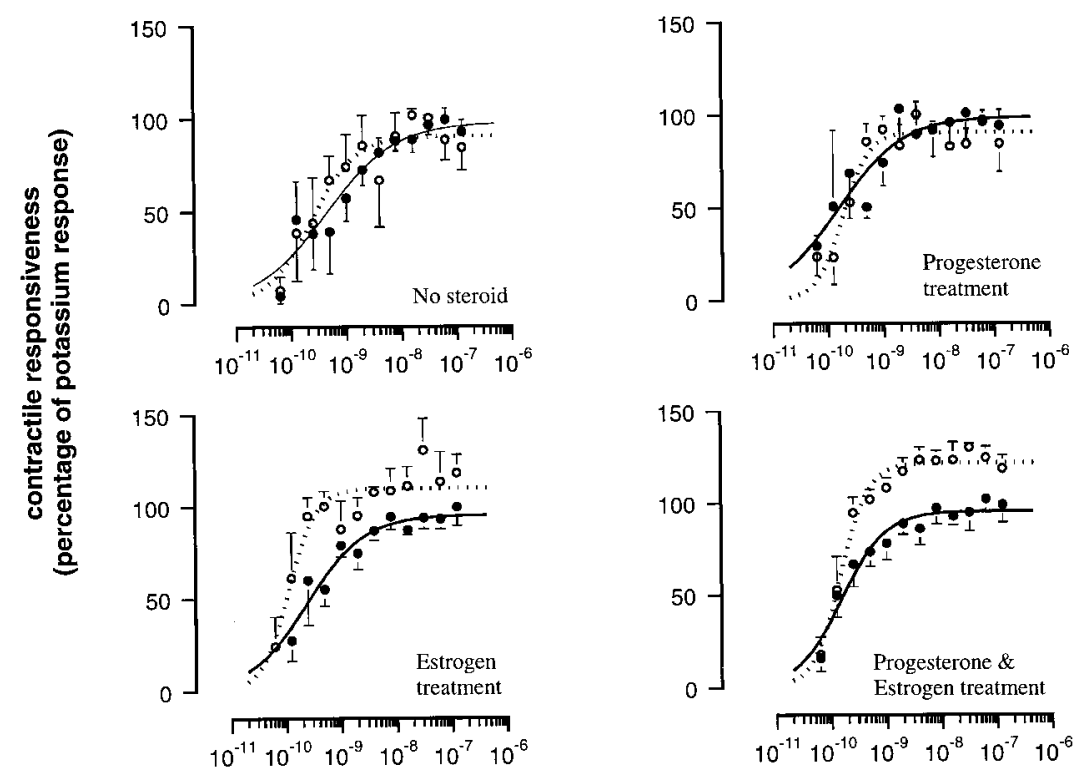

\section{oxytocin concentration (M)}

Figure 3 Dose-response curves of isolated uterine strips challenged with oxytocin. Strips were obtained from rats treated with estradiol-benzoate $(50 \mu \mathrm{g} \times 1$, i.m.), progesterone $(100 \mu \mathrm{g} \times 1$, i.m.) or a combination of both (same doses as in individual regimens) for 3 days. The rats were additionally treated with saline $(1 \mu \mathrm{l} / \mathrm{h}, \boldsymbol{\bullet})$ or isoproterenol $(10 \mu \mathrm{g} / \mathrm{h}$, O) for 3 days. Values are means \pm S.E.M., $n=3-4$.

Isoproterenol infusion increased OTR mRNA 13-fold in the progesterone treatment group $(P=0 \cdot 047)$ and 5 -fold in the combined steroid treatment group $(P=0 \cdot 040)$. In contrast isoproterenol had no effect on OTR mRNA in the control group or the estrogen treatment group.

Binding of $\left[{ }^{3} \mathrm{H}\right]$-oxytocin to isolated myometrial plasma membranes

Specific binding of $\left[{ }^{3} \mathrm{H}\right]$-oxytocin to isolated plasma membranes was saturable and time-dependent. Equilibrium was attained after $15 \mathrm{~min}$. Double reciprocal plots revealed binding sites of only a single affinity and they were used to calculate receptor affinity $\left(K_{\mathrm{D}}\right)$ and maximal specific binding $\left(\mathrm{B}_{\max }\right)$ values.

$\mathrm{B}_{\max }$ between steroid treatment groups not receiving isoproterenol were statistically different $(P<0 \cdot 001)$. Posthoc analysis showed that estrogen treatment increased $\mathrm{B}_{\max }$ when compared with the control group $(P<0 \cdot 05$, Fig. 2$)$. This increase was blocked by co-treatment with progesterone. Progesterone treatment alone did not alter $\mathrm{B}_{\max }$ when compared with control (Fig. 2). Isoproterenol treatment enhanced $\mathrm{B}_{\max }$ in both the progesterone $(P<0 \cdot 001)$ and the combined steroid group $(P=0 \cdot 010)$ but not in the control or estrogen group.
$K_{\mathrm{D}}$ values were in the nanomolar range and they varied from $0.67 \pm 0.30$ to $1.32 \pm 0.79 \mathrm{nM}$. No statistical differences were found between the groups.

\section{Contractile activity of isolated uterine strips}

Dose-response curves from oxytocin stimulated uterine strips are shown in Fig. 3. Both maximal contractile effect $\left(E_{\max }\right)$ and the concentration giving half this effect (EC50) were unaffected by any of the steroid treatments $(P=0 \cdot 830$ and $P=0.252$ respectively, Table 1$)$. Isoproterenol infusion significantly increased $\mathrm{E}_{\max }$ by $30 \%$ in the estrogen treatment group $(P=0 \cdot 029)$. However, when both estrogen and progesterone were administered isoproterenol enhanced $\mathrm{E}_{\max }$ further, namely by $40 \%(P=0 \cdot 004)$. EC50 values were left unchanged following isoproterenol treatment in all groups.

To investigate whether the effects of $\beta_{2}$-stimulation on myometrial contractility were merely caused by general metabolic changes induced by isoproterenol we compared uterine responses to potassium chloride among the different experimental groups. No significant changes were found between isoproterenol infused rats and control rats in either of the steroid treatment groups $(3 \cdot 03 \pm 0 \cdot 60$ vs $2.91 \pm 0.70 \mathrm{~g}$ (isoproterenol vs control, no steroid), $3.85 \pm 0.73$ vs $4.84 \pm 1.28 \mathrm{~g}$ (isoproterenol vs control, 
Table $1 \mathrm{EC50}$ and $\mathrm{E}_{\max }$ values of isolated uterine strips challenged with oxytocin. Uteri were isolated from rats treated for 3 days with estradiol-benzoate $(50 \mu \mathrm{g} \times 1)$, progesterone $(100 \mu \mathrm{g} \times 1)$ and isoproterenol $(10 \mu \mathrm{g} / \mathrm{h})$ in the combinations indicated. Values are means \pm S.E.M., $n=3-4$

\begin{tabular}{|c|c|c|}
\hline & $\begin{array}{l}\text { EC50 } \\
(\mathrm{nM})\end{array}$ & $\begin{array}{l}\mathbf{E}_{\max } \\
\text { (\% of } \mathrm{KCl} \text { response) }\end{array}$ \\
\hline \multicolumn{3}{|l|}{ Treatment } \\
\hline Vehicle & $0 \cdot 75 \pm 0 \cdot 34^{\text {n.s. }}$ & $94 \cdot 3 \pm 3 \cdot 82$ \\
\hline Vehicle+isoproterenol & $0 \cdot 51 \pm 0 \cdot 27$ & $94 \cdot 7 \pm 6 \cdot 88^{\text {n.s. }}$ \\
\hline Estrogen & $0 \cdot 42 \pm 0 \cdot 14$ & $93 \cdot 3 \pm 2 \cdot 59$ \\
\hline Estrogen + isoproterenol & $0 \cdot 47 \pm 0 \cdot 25^{\text {n.s. }}$ & $122 \cdot 0 \pm 13 \cdot 1^{*}$ \\
\hline Progesterone & $0 \cdot 18 \pm 0 \cdot 10$ & $98 \cdot 0 \pm 12 \cdot 2$ \\
\hline Progesterone+isoproterenol & $0 \cdot 17 \pm 0 \cdot 06^{\text {n.s. }}$ & $91 \cdot 0 \pm 4 \cdot 34^{\text {n.s. }}$ \\
\hline Estrogen + progesterone & $0 \cdot 22 \pm 0 \cdot 09$ & $89 \cdot 3 \pm 6 \cdot 75$ \\
\hline Estrogen + progesterone + isoproterenol & $0 \cdot 15 \pm 0 \cdot 03^{\text {n.s. }}$ & $123 \cdot 0 \pm 3 \cdot 46^{* *}$ \\
\hline
\end{tabular}

${ }^{*} P<0 \cdot 05,{ }^{* *} P<0 \cdot 005 ;$ n.s.: statistically insignificant.

estrogen treatment), $1.90 \pm 0.37$ vs $2.28 \pm 0.33 \mathrm{~g}$ (isoproterenol vs control, progesterone treatment) and $3.71 \pm 0.38$ vs $4.13 \pm 0.67 \mathrm{~g}$ (isoproterenol vs control, progesterone plus estrogen treatment)).

\section{Discussion}

The present study shows that rat myometrial OTR gene expression and OTR binding are under the influence of $\beta_{2}$-adrenoceptor activation and gonadal steroids. Estrogen treatment alone increased both parameters but did not affect myometrial contractility when evaluated by means of isolated uterine strips stimulated with oxytocin. On the other hand, when estrogen was combined with isoproterenol an augmented $\mathrm{E}_{\max }$ was observed although no further increase in OTR mRNA and binding was seen. Progesterone did not in itself alter OTR mRNA, OTR binding or maximal contractility of isolated uterine strips. However, OTR formation was induced at the level of gene expression when progesterone injections were supplemented with isoproterenol infusion. Finally progesterone suppressed the effect of estrogen on mRNA production and binding when the two compounds were administered together. However, when isoproterenol treatment was added this effect was abolished and the maximal contractile ability of oxytocin on isolated strips was enhanced more than that seen following treatment with estrogen alone.

The induction of OTR expression by estrogen shown in the present study is in accordance with previous findings (Alexandrova \& Soloff 1980, Fuchs et al. 1983a,b). It is promoted by activation of an estrogen response element within the OTR gene (Bale \& Dorsa 1997). The contractile ability of isolated uterine strips challenged with oxytocin, however, remained unchanged in estrogen treated rats unless the treatment was supplemented with isoproterenol infusion. Because isoproterenol did not alter the binding of $\left[{ }^{3} \mathrm{H}\right]$-oxytocin, the effect of isoproterenol appears not to be mediated by a direct isoproterenol-OTR interaction. In addition, in the estrogen treated group, OTR mRNA and binding were unaffected by isoproterenol when compared with the estrogen treatment alone. We thus suggest that $\beta_{2}$-adrenoceptor activation may augment the coupling between OTR occupancy and contractile responsiveness. Since $\beta_{2}$-adrenoceptor stimulation raises intracellular cAMP and OTR activation increases phospholipase $\mathrm{C}$ activity the mechanism described constitutes an example of cross-talk between two different receptor-effector systems. Likewise, Pittner \& Fain (1989, 1990) observed that intracellular signaling of another phospholipase C linked receptor, namely the hepatic vasopressin receptor, was enhanced by cAMP-dependent kinase (protein kinase A).

The ability of oxytocin to induce contractions of isolated uterine strips is dependent on intact intercellular communications, which are mainly controlled by the presence of gap junctions (Garfield et al. 1988). Gap junctionmediated intercellular communication was enhanced following treatment with the cAMP analogue 8-bromocAMP of both human (Burghardt et al. 1996) and rabbit (Nnamani et al. 1994) myometrial cells. In addition, the gap junction protein connexin-43 was regulated independently of estrogen receptor concentrations in human myometrium (Geimonen et al. 1998) and we therefore speculate whether the increase in $\mathrm{E}_{\max }$ following isoproterenol infusion in the estrogen treated group may originate from a rise in the number of gap junctions.

The effects of isoproterenol on OTR mRNA and binding in the progesterone treated group are in agreement with the finding by Bale \& Dorsa (1998) who found the OTR gene to contain a cAMP response element which enhances OTR transcription. However, in the presence of progesterone, isoproterenol did not increase the myometrial response to oxytocin, suggesting that newly formed OTRs remain uncoupled in the absence of other stimuli. Several mechanisms may account for the 
lack of coupling of those OTRs induced by combined treatment with isoproterenol and progesterone. As observed by Lécrivain et al. (1998) $G_{\alpha}$ is increased by isoproterenol in pregnant rat myometrium and thus OTR signaling may be altered. Other explanations may include progesterone-induced alterations in myosin light-chain kinase activity promoted by cAMP dependent phosphorylation of this enzyme (Badia et al. 1986) or a negative effect of progesterone on gap junction formation as suggested by Hendrix et al. (1995).

When both estrogen and progesterone were administered the enhancing effect of isoproterenol on OTR production was paralleled by an increase in $\mathrm{E}_{\max }$, which was more pronounced than the effect of isoproterenol on $\mathrm{E}_{\max }$ when estrogen was the only steroid given. This might indicate that the enhancing effect of $\beta_{2}$-adrenoceptor activation on the synthesis of functional OTR operates only in the presence of both steroids. Nevertheless, the fact that isoproterenol was not able to increase OTR mRNA and binding among estrogen treated rats is apparently intriguing due to the presence of the cAMP response element within the OTR gene. However, estrogen is, in itself, a strong promoter of OTR expression, and the relatively high dose of estrogen administered might therefore increase OTR transcription rate to an extent which blunts a qualitatively similar effect of $\beta_{2}$-adrenoceptor activation.

A proposed role of $\beta_{2}$-adrenoceptor stimulation in the up-regulation of OTR may appear contradictory, since we have earlier published that isoproterenol in vitro attenuates myometrial contractility (Engstrøm et al. 1997). Indeed, obstetricians use $\beta_{2}$-stimulation to prevent pre-term labour (Caritis et al. 1983). Several studies have, however, shown that continuous exposure to tocolytics of this kind results in a loss of myometrial responsiveness to subsequent $\beta_{2}$-adrenoceptor activation (Berg et al. 1985, Abel \& Hollingsworth 1986). Based on the present results we suggest that this effect may involve the induction of OTR expression.

Myometrial sensitivity to oxytocin is increased at term primarily due to a rise in the number of OTRs (Hirata et al. 1996). Some studies have shown that rat (Larcher et al. 1995, Quinones Jenab et al. 1997), rabbit (Jacobson et al. 1987) and ewe (Crankshaw et al. 1982) OTR are up-regulated by estrogens and down-regulated by progesterone. It has thus been proposed that the withdrawal of progesterone observed in rodents prior to term constitute the signal responsible for the up-regulation of OTR and the subsequent initiation of parturition (Csapo 1956). The idea of progesterone withdrawal as a prerequisite for parturition is, however, not valid in all species. In guinea pig (Porter 1970) and human pregnancy (Yannone et al. 1968, Tulchinsky et al. 1972) progesterone levels do not decline before the onset of labor and in human pregnancy (Lofgren \& Backstrom 1997) high progesterone concentrations during parturition appeared to be related to effective labor. Interestingly, Vallet et al. (1990) observed an increase in ewe uterine OTR following 12 days progesterone treatment and in accordance with the present results, Ruzycky \& Crankshaw (1988) observed no inhibitory effect of progesterone on oxytocin induced uterine contractility in estrogen dominated rats. Even within the same species the effects of progesterone on OTR differ in different tissues (Kremarik et al. 1995). These observations altogether suggest that other factors than progesterone and estrogen influence myometrial OTR expression and function. In this context, and in view of the remarkable increase in maternal catecholamines (Suzuki et al. 1989) during labor, our results suggest that $\beta_{2}$-adrenoceptor activation may be of importance.

\section{Acknowledgements}

The present study was supported by The Danish Biotechnology Programme, Brødrene Hartmanns Foundation, The Danish Medical Research Council, The Novo Nordisk Foundation, The Beckett Foundation, 'Direktør Jacob Madsen \& Hustru Olga Madsens Fond', The Danish Medical Association Research Fund, 'Emil Søeborg Ohlsen og æatefælle Else Søeborg Ohlsens mindelegat' and 'Ove Villiam Buhl Olesen \& ægtefælle Edith Buhl Olesens Foundation', 'Else \& Mogens WedellWedellsborgs Fond' and 'Foundation Idella'. We thank technicians Gurli Habekost, Jakob Utzon-Frank and Grethe Thaarup for their helpful assistance.

\section{References}

Abel MH \& Hollingsworth M 1986 Comparison of nifedipine and diltiazem with salbutamol for prevention of preterm delivery in the ovariectomized, oestrogen-treated late pregnant rat. Journal of Reproduction and Fertility 77 559-568.

Alexandrova M \& Soloff MS 1980 Oxytocin receptors and parturition. I. Control of oxytocin receptor concentration in the rat myometrium at term. Endocrinology 106 730-735.

Altschul SF, Gish W, Miller W, Myers EW \& Lipman DJ 1990 Basic local alignment search tool. Journal of Molecular Biology 215 403-410.

Anwer K, Hovington JA \& Sanborn BM 1989 Antagonism of contractants and relaxants at the level of intracellular calcium and phosphoinositide turnover in the rat uterus. Endocrinology, 124 2995-3002.

Anwer K, Hovington JA \& Sanborn BM 1990 Involvement of protein kinase $\mathrm{A}$ in the regulation of intracellular free calcium and phosphoinositide turnover in rat myometrium. Biology of Reproduction 43 851-859.

Badia E, Nicolas JC, Haiech J \& Crastes de Paulet A 1986 Effect of steroid hormones on the regulation of uterine contractility. Pflugers Archiv 407 670-676.

Bale T \& Dorsa D 1997 Cloning, novel promoter sequence, and estrogen regulation of a rat oxytocin receptor gene. Endocrinology 138 1151-1158.

Bale TL \& Dorsa DM 1998 NGF, cyclic AMP, and phorbol esters regulate oxytocin receptor gene transcription in SK-N-SH and MCF7 cells. Molecular Brain Research 53 130-137. 
Berg G, Andersson RG \& Ryden G 1985 Beta-adrenergic receptors in human myometrium during pregnancy: changes in the number of receptors after beta-mimetic treatment. American Journal of Obstetrics and Gynecology 151 392-396.

Burghardt RC, Barhoumi R, Stickney M, Monga M, Ku CY \& Sanborn BM 1996 Correlation between connexin43 expression, cell-cell communication, and oxytocin-induced $\mathrm{Ca}^{2+}$ responses in an immortalized human myometrial cell line. Biology of Reproduction 55 433-438.

Caritis SN, Lin LS, Toig G \& Wong LK 1983 Pharmacodynamics of ritodrine in pregnant women during preterm labor. American Journal of Obstetrics and Gynecology 147 752-759.

Crankshaw DJ, Romaniuk E \& Branda LA 1982 Identification and characterization of receptors for oxytocin in the myometrium of the pregnant ewe. Gynecologic and Obstetric Investigation 14 202-213.

Csapo AI 1956 Progesterone block. American Journal of Anatomy 98 273-291.

Engstrøm T, Atke A \& Vilhardt H 1988a Receptor-binding characteristics and contractile responsiveness of the myometrium following prolonged infusion of bradykinin and oxytocin in rats. Journal of Endocrinology 118 81-85.

Engstrøm T, Atke A \& Vilhardt H 1988 b Oxytocin receptors and contractile response of the myometrium after long term infusion of prostaglandin F2 alpha, indomethacin, oxytocin and an oxytocin antagonist in rats. Regulatory Peptides 20 65-72.

Engstrøm T, Bratholm P, Vilhardt H \& Christensen NJ 1997 Effect of pregnancy on rat myometrial beta 2-adrenoceptor mRNA and isoproterenol-induced relaxation of isolated uterine strips. Journal of Endocrinology 153 393-399.

Engstrøm T, Bratholm P, Vilhardt H \& Christensen NJ 1998 $\beta_{2}$-desensitization in non-pregnant estrogen primed rat myometrium involves modulation of oxytocin receptor gene expression. Journal of Molecular Endocrinology 20 261-270.

Faure C, Gouhier C, Langer SZ \& Graham D 1995 Quantification of alpha-1-adrenoceptor subtypes in human tissues by competitive RT-PCR analysis. Biochemical and Biophysical Research Communications 213 935-943.

Fuchs AR, Periyasamy S, Alexandrova M \& Soloff MS 1983a Correlation between oxytocin receptor concentration and responsiveness to oxytocin in pregnant rat myometrium: effects of ovarian steroids. Endocrinology 113 742-749.

Fuchs AR, Periyasamy S \& Soloff MS 1983b Systemic and local regulation of oxytocin receptors in the rat uterus, and their functional significance. Canadian Journal of Biochemistry and Cell Biology 61 615-624.

Fuchs AR, Helmer H, Behrens O, Liu HC, Antonian L, Chang SM \& Fields MJ 1992 Oxytocin and bovine parturition: a steep rise in endometrial oxytocin receptors precedes onset of labor. Biology of Reproduction 47 937-944.

Ganjam VK, Kenney RM \& Flickinger G 1975 Effect of exogenous progesterone on its endogenous levels: biological half-life of progesterone and lack of progesterone binding in mares. Journal of Reproduction and Fertility 23 183-188.

Garfield RE, Blennerhassett MG \& Miller SM 1988 Control of myometrial contractility: role and regulation of gap junctions. Oxford Review of Reproductive Biology 10 436-490.

Geimonen E, Boylston E, Royek A \& Andersen J 1998 Elevated connexin-43 expression in term human myometrium correlates with elevated c-Jun expression and is independent of myometrial estrogen receptors. Journal of Clinical Endocrinology and Metabolism 83 $1177-1185$.

Grazzini E, Guillon G, Mouillac B \& Zingg HH 1998 Inhibition of oxytocin receptor function by direct binding of progesterone. Nature 392 509-512.

Hendrix EM, Myatt L, Sellers S, Russell PT \& Larsen WJ 1995 Steroid hormone regulation of rat myometrial gap junction formation: effects on cx43 levels and trafficking. Biology of Reproduction 52 547-560.
Hilliard J, Spies HG \& Sawyer CH 1968 Cholesterol storage and progestin secretion during pregnancy and pseudopregnancy in the rabbit. Endocrinology 82 157-165.

Hirata J, Kikuchi Y, Imaizumi E, Furuya K \& Nagata I 1996 Correlation between the stimulatory effect of oxytocin on the formation of inositol phosphates and the oxytocin receptor level in the pregnant rabbit myometrium. Journal of Obstetrics and Gynaecology 22 497-506.

Hixon JE \& Flint AP 1987 Effects of a luteolytic dose of oestradiol benzoate on uterine oxytocin receptor concentrations, phosphoinositide turnover and prostaglandin F-2 alpha secretion in sheep. Journal of Reproduction and Fertility 79 457-467.

Jacobson L, Riemer RK, Goldfien AC, Lykins D, Siiteri PK \& Roberts JM 1987 Rabbit myometrial oxytocin and alpha 2 -adrenergic receptors are increased by estrogen but are differentially regulated by progesterone. Endocrinology 120 1184-1189.

Jeng YJ, Hinko A \& Soloff MS 1995 Effectors of cyclic adenosine $5^{\prime}$-monophosphate up-regulating oxytocin receptors in rabbit amnion cells: isoproterenol, parathyroid hormone-related protein, and potentiation by cortisol. Biology of Reproduction $\mathbf{5 3}$ 1051-1056.

Kremarik P, Freund Mercier MJ \& Stoeckel ME 1995 Estrogensensitive oxytocin binding sites are differently regulated by progesterone in the telencephalon and the hypothalamus of the rat. Journal of Neuroendocrinology 7 281-289.

Larcher A, Neculcea J, Breton C, Arslan A, Rozen F, Russo C \& Zingg HH 1995 Oxytocin receptor gene expression in the rat uterus during pregnancy and the estrous cycle and in response to gonadal steroid treatment. Endocrinology 136 5350-5356.

Lau TM, Kerton DJ, Gow CB \& Fairclough RJ 1992 Increase in concentration of uterine oxytocin receptors and decrease in response to 13,14-dihydro-15-keto prostaglandin F2 alpha in ewes after withdrawal of exogenous progesterone. Journal of Reproduction and Fertility 95 885-893.

Lécrivain JL, Cohen Tannoudji J, Robin MT, Coudouel N, Legrand C \& Maltier JP 1998 Molecular mechanisms of adenylyl cyclase desensitization in pregnant rat myometrium following in vivo administration of the beta-adrenergic agonist, isoproterenol. Biology of Reproduction $\mathbf{5 9} 45-52$.

Lofgren M \& Backstrom T 1997 High progesterone is related to effective human labor. Study of serum progesterone and 5alpha-pregnane-3,20-dione in normal and abnormal deliveries. Acta Obstetricia et Gynecologica Scandinavica 76 423-430.

Lowry OH, Rosebrough NJ, Farr AL \& Randall RJ 1951 Protein measurement with the Folin phenol reagent. Journal of Biological Chemistry 193 265-275.

Munsick RA 1960 Effect of magnesium ion on the response of the rat uterus to neurohypophysial hormones and analogues. Endocrinology 66 451-457.

Nnamani C, Godwin A, Ducsay CA, Longo LD \& Fletcher WH 1994 Regulation of cell-cell communication mediated by connexin 43 in rabbit myometrial cells. Biology of Reproduction $\mathbf{5 0}$ 377-389.

Pittner RA \& Fain JN 1989 Exposure of cultured hepatocytes to cyclic AMP enhances the vasopressin-mediated stimulation of inositol phosphate production. Biochemical Journal 257 455-460.

Pittner RA \& Fain JN 1990 Vasopressin and norepinephrine stimulation of inositol phosphate accumulation in rat hepatocytes are modified differently by protein $\mathrm{f} 1$ nase $\mathrm{C}$ and protein kinase A. Biochimica et Biophysica Acta 1043 211-217.

Porter DG 1970 The failure of progesterone to affect myometrial activity in the guinea-pig. Journal of Endocrinology 46 425-434.

Quinones Jenab V, Jenab S, Ogawa S, Adan RA, Burbach JP \& Pfaff DW 1997 Effects of estrogen on oxytocin receptor messenger ribonucleic acid expression in the uterus, pituitary, and forebrain of the female rat. Neuroendocrinology 65 9-17. 
Rozen F, Russo C, Banville D \& Zingg HH 1995 Structure, characterization, and expression of the rat oxytocin receptor gene (published erratum appears in Proceedings of the National Academy of Sciences of the USA 199693 12051). Proceedings of the National Academy of Sciences of the USA 92 200-204.

Ruzycky AL \& Crankshaw DJ 1988 Role of inositol phospholipid hydrolysis in the initiation of agonist-induced contractions of rat uterus: effects of domination by 17 beta-estradiol and progesterone. Canadian Journal of Physiology and Pharmacology 66 10-17.

Sheldrick EL \& Flint AP 1985 Endocrine control of uterine oxytocin receptors in the ewe. Journal of Endocrinology 106 249-258.

Sheldrick EL \& Flick Smith HC 1993 Effect of ovarian hormones on oxytocin receptor concentrations in explants of uterus from ovariectomized ewes. Journal of Reproduction and Fertility $\mathbf{9 7}$ 241-245.

Silvia WJ, Lewis GS, McCracken JA, Thatcher WW \& Wilson L Jr. 1991 Hormonal regulation of uterine secretion of prostaglandin F2 alpha during luteolysis in ruminants. Biology of Reproduction $\mathbf{4 5}$ 655-663.

Stürmer E 1968 The rat uterus assay procedure. In Handbook of Experimental Pharmacology, pp 130-189. Ed B Berde. Berlin, Heidelberg, New York: Springer Verlag.
Suzuki A, Hashino M, Chiba H, Saito H, Notake Y, Yanaihara T \& Nakayama T 1989 Correlation between the levels of catecholamines (noradrenaline, adrenaline) and adrenal steroids (DHA-S, cortisol) in maternal and fetal blood during pregnancy and labor. Journal of the Japan Veterinary Medical Association 65 704-714.

Tulchinsky D, Hobel CJ, Yeager E \& Marshall JR 1972 Plasma estrone, estradiol, estriol, progesterone, and 17-hydroxyprogesterone in human pregnancy. I. Normal pregnancy. American Journal of Obstetrics and Gynecology 112 1095-1100.

Vallet JL, Lamming GE \& Batten M 1990 Control of endometrial oxytocin receptor and uterine response to oxytocin by progesterone and oestradiol in the ewe. Journal of Reproduction and Fertility $\mathbf{9 0}$ 625-634.

Yannone ME, McCurdy JR \& Goldfien A 1968 Plasma progesterone levels in normal pregnancy, labor, and the puerperium. II. Clinical data. American Journal of Obstetrics and Gynecology 101 1058-1061.

Received 25 September 1998

Revised manuscript received 22 December 1998 Accepted 26 January 1999 